\title{
Effect of Rice Bran Quality and Protein Supplement, Base Mix, and/or Soybean Meal on Growing Pig Performance in Cambodia
}

\author{
Chenda En ${ }^{*}$, Sath Keo², Jessie L. Vipham³ ${ }^{3}$ Bunna Chea², Kroesna Kang², Michael D. Tokach ${ }^{3}$, \\ Joel M. DeRouchey ${ }^{3}$
}

${ }^{1}$ Faculty of Animal Science, Royal University of Agriculture, Phnom Penh, Cambodia

${ }^{2}$ Faculty of Veterinary Medicine, Royal University of Agriculture, Phnom Penh, Cambodia

${ }^{3}$ Department of Animal Sciences and Industry, Kansas State University, Manhattan, USA

Email: *chendaenstrong@gmail.com

How to cite this paper: En, C., Keo, S., Vipham, J.L., Chea, B., Kang, K., Tokach, M.D. and DeRouchey, J.M. (2020) Effect of Rice Bran Quality and Protein Supplement, Base Mix, and/or Soybean Meal on Growing Pig Performance in Cambodia. Open Journal of Animal Sciences, 10, 714-724. https://doi.org/10.4236/ojas.2020.104046

Received: September 9, 2020

Accepted: October 16, 2020

Published: October 19, 2020

Copyright $\odot 2020$ by author(s) and Scientific Research Publishing Inc. This work is licensed under the Creative Commons Attribution International License (CC BY 4.0).

http://creativecommons.org/licenses/by/4.0/

(c) (i) Open Access

\begin{abstract}
The objective of this study was to evaluate the effect of rice bran quality and dietary supplement source on growing pig performance. A total of $60 \mathrm{ca}-$ strated male pigs (Yorkshire $\times$ Duroc, initially $16.1 \mathrm{~kg}$ ) were used for 52-day trial. Pigs were allotted to pens in a completely randomized design (4 pigs per pen) and assigned to four dietary treatments in a $2 \times 2$ factorial with factors being rice bran source (high or low-quality) and source of protein, vitamins, and minerals (supplement or soybean meal and base mix). Analyzed protein and fat level for the high- and low-quality rice bran was $11.07 \%$ and $5.86 \%$ and $11.20 \%$ and $4.50 \%$, respectively. Crude fiber content for high- and low-quality rice bran was $13.44 \%$ and $27.79 \%$. Diets were formulated in two phases (phase 1: 16 to 27 and phase 2: 27 to $48 \mathrm{~kg}$ ) to adjust to the pig's nutrient requirements. There was no evidence for an interaction $(\mathrm{P}>0.05)$ between rice bran quality $\times$ supplement type or main effect of supplement type (soybean meal + base mix vs protein supplement) for final body weight, average daily gain $(A D G)$, average daily feed intake (ADFI), and feed efficiency $(\mathrm{F} / \mathrm{G})$. However, pigs fed high-quality rice bran had improved $(\mathrm{P}<0.001)$ $\mathrm{ADG}$ and $\mathrm{F} / \mathrm{G}$ and lower ADFI compared to pigs fed low protein rice bran. In conclusion, rice bran quality as measured by protein, crude fiber, and fat influenced growing pig performance, while the type of dietary protein supplement did not. Additionally, rice bran with high protein, fat, and low fiber improved ADG and F/G.
\end{abstract}

\section{Keywords}

Base Mix, Pigs, Protein Supplement, Rice Bran, Soybean Meal 


\section{Introduction}

Animal production has the potential to improve human wellbeing and prosperity in resource poor communities around the world. In Cambodia, pig production makes an important contribution to farm and family incomes [1]. Although the Ministry of Agriculture, Forestry, and Fisheries [2] reported that the number of pigs raised in Cambodia to be 2,185,924 heads, consumer demand for pork exceeds the countries production capacity (estimated at 153 thousand ton). In terms of local production, $75 \%$ of total pig producers are farmers living in the rural provinces of Cambodia [3]. Commonly, these small farm-households raise pigs in small numbers, utilizing traditional farm management techniques [4]. This includes feeding ingredients that are commonly available in Cambodia, such as rice bran, banana stem, sweet potato vine, water spinach, water hyacinth, duckweed, and other non-conventional feed [5]. Rice bran is a by-product of processing paddy rice for human food and is often used as an ingredient in mixed pig feed [6]. Due to its interesting chemical composition and particularly high lysine and methionine content, rice bran is often used as a basal diet in pigs [5] [7] [8] [9] [10]. Rice bran can be a mixture of by-products obtained from different stages of the milling process, which results in large variations in its chemical composition. In Cambodia, rice bran is used in up to $50 \%$ of the feeds for pigs [1] and it is commonly marketed based upon three grades (1, 2, and 3) according to their nutritional value and physical texture. Cambodian rice bran, produced by traditional mills, has low energy density and protein [5]. The classification of rice bran grade is based on qualifications of rice mills, machinery, rice milled processing, and price of rice bran in the region [1]. There is a large variation in the nutrient quality of rice bran in Cambodia where Sreng [11] recently reported crude protein ranges of $13.20 \%, 10.86 \%$ and $7.32 \%$ crude protein for rice bran grades 1,2 , and 3 , respectively. Also, crude fiber levels were found between grades 1, 2 and 3 with values of $15.57 \%, 15.31 \%$ and $26.22 \%$. Rice bran purchased from mills producing grade 3 rice bran based on nutrient profile may result in slower growth and lower performance and productivity of pigs, due to lower levels of energy, protein [10] and minerals [12]. Cambodian farmers are often aware of this fact and often mix rice bran with other protein sources to improve pig growth.

Commercial protein supplements are often purchased and utilized by Cambodian farmers to mix with rice bran or other grain sources in pig diets. These protein supplements are a good source of protein and may include some vitamins and minerals. However, they are expensive, and farmers often cannot afford to feed them at recommended levels. This leads to farmers adding reduced levels of protein supplements to pig diets, which does not ultimately lead to improved nutrition outcomes for pigs. Additionally, some small-scale farmers will purchase vitamins and mineral, available as a base mix or premix, in an attempt to provide better nutrients to pig diets. However, it has been shown that the addition of a base mix or premix to rice bran does not provide sufficient protein to 
meet the nutrition requirements for pigs [13]. Currently there is a lack of research evaluating different rice bran sources with soybean meal, commercial protein supplements or the addition of a base mix to rice bran-based diet. Thus, the objective of this study was to evaluate the effect of rice bran source and supplement source (commercial supplement or soybean meal and base mix) on growth performance of growing pigs.

\section{Material and Methods}

\subsection{Location and Duration}

This study was conducted in an on-farm setting in a farmer's pig barn facility located in Kandal province, approximately $20 \mathrm{~km}$ from Phnom Penh, Cambodia. The study was conducted over a 3-month period, during the dry season (April to June 2019). The average daily temperature of $31^{\circ} \mathrm{C}$ (maximum at $32^{\circ} \mathrm{C}$ and minimum at $29^{\circ} \mathrm{C}$ ) and $74 \%$ humidity (range $66 \%-81 \%$ ). The Kansas State University Institutional Animal Care and use committee approved the research of this experiment.

\subsection{Animal and Management}

A total of 60-castrated-pigs (Yorkshire $\times$ Duroc), with a starting weight of approximately $16 \mathrm{~kg}$, were randomly assigned, in a completely randomized design, to individual pens $(2 \times 3 \mathrm{~m})$ with free access to one feeder and one available water drinker. Four pigs were assigned to each pen, based on starting body weight to achieve an equal starting weight across the four-feeding comparison. Pigs were vaccinated against Mycoplasma, foot and mouth disease, porcine respiratory and reproductive syndrome, and classical swine fever and also were treated Bendazole to kill roundworms before starting the experiment.

\subsection{Feed and Feeding}

The experiential diets consisted of soybean meal, protein supplement, two grades of rice bran and base mix. Feed ingredients were purchased from a local feed store and rice milling near the experimental farm, except base mix, which was purchased from Provimi Company in Vietnam. Pigs were fed with complete feed (Higro 550, CP Cambodia Co., Ltd.) for 4 days during pen adaptation and then pigs were adapted for 3 days with experimental trial diet before starting the experiment. Feed was mixed thoroughly one day prior to offering feed (Table 1).

Treatments were arranged in a $2 \times 2$ factorial with two rice bran sources (high or low-quality based on protein and fat content) and two supplement types (soybean meal plus base mix or protein supplement). There were 3 or 4 replications per treatment. Experimental diets were formulated in two phases according to stage growth of pigs: phase 1 . Pigs with a body weight of $16-27 \mathrm{~kg}$; and phase 2. Pigs with a body weight of 27 - $48 \mathrm{~kg}$ (Table 1). Diets using protein supplement contained a constant $20 \%$ inclusion rate for both phases, according to the recommendation of manufacturer. Soybean meal was reduced between phase 1 
Table 1. Composition of basal diet used in the experiment (as-fed basis).

\begin{tabular}{|c|c|c|c|c|c|}
\hline Diet & $\begin{array}{l}\text { High-quality } \\
\text { rice bran }\end{array}$ & $\begin{array}{l}\text { Low-quality } \\
\text { rice bran }\end{array}$ & $\begin{array}{c}\text { Protein } \\
\text { Supplement }\end{array}$ & Soybean Meal & Base mix $^{a}$ \\
\hline \multicolumn{6}{|c|}{ Phase 1 (16 - $27 \mathrm{~kg}$ of body weight) } \\
\hline Diet 1 & 72.5 & - & - & 25 & 2.5 \\
\hline Diet 2 & 80 & - & 20 & - & - \\
\hline Diet 3 & - & 72.5 & - & 25 & 2.5 \\
\hline Diet 4 & - & 80 & 20 & - & - \\
\hline \multicolumn{6}{|c|}{ Phase 2 (27 - $48 \mathrm{~kg}$ of body weight) } \\
\hline Diet 1 & 79.5 & - & - & 18 & 2.5 \\
\hline Diet 2 & 80 & - & 20 & - & - \\
\hline Diet 3 & - & 79.5 & - & 18 & 2.5 \\
\hline Diet 4 & - & 80 & 20 & - & - \\
\hline
\end{tabular}

${ }^{\mathrm{a} C o m p o s i t i o n ~ o f ~ B a s e ~ m i x ~ p e r ~ k g: ~ V i t a m i n ~ A ~=~ 206,250 ~ I U / k g ; ~ V i t a m i n ~ D 3 ~=~ 422,00 ~ I U / k g ; ~ C h o l i n e ~=~}$ $13,700 \mathrm{mg} / \mathrm{kg}$; Vitamin E = $1690 \mathrm{mg} / \mathrm{kg}$; Vitamin B3 = $1240 \mathrm{mg} / \mathrm{kg}$; Vitamin B5 = $685 \mathrm{mg} / \mathrm{kg} ;$ Vitamin B2 = $206 \mathrm{mg} / \mathrm{kg}$; Vitamin K = $84 \mathrm{mg} / \mathrm{kg}$; Folic acid $=56 \mathrm{mg} / \mathrm{kg}$; Vitamin B6 $=28 \mathrm{mg} / \mathrm{kg}$; Biotin = $5.6 \mathrm{mg} / \mathrm{kg}$; Vi$\operatorname{tamin~} \mathrm{B} 12=850 \mathrm{mg} / \mathrm{kg} ; \mathrm{Fe}\left(\mathrm{FeSO}_{4}-\mathrm{H}_{2} \mathrm{O}\right)=2750 \mathrm{mg} / \mathrm{kg} ; \mathrm{Zn}(\mathrm{ZnO})=2750 \mathrm{mg} / \mathrm{kg} ; \mathrm{Mn}(\mathrm{MnO})=825 \mathrm{mg} / \mathrm{kg} ;$ $\mathrm{Cu}\left(\mathrm{CuSO}_{4}-5 \mathrm{H}_{2} \mathrm{O}\right)=415 \mathrm{mg} / \mathrm{kg} ; \mathrm{Se}\left(\mathrm{Na}_{2} \mathrm{SeO}_{2}\right)=7.4 \mathrm{mg} / \mathrm{kg} ; \mathrm{I}\left(\mathrm{Ca}\left(\mathrm{IO}_{3}\right)_{2}-\mathrm{H}_{2} \mathrm{O}\right)=7.4 \mathrm{mg} / \mathrm{kg} ;$ Lysine $(\mathrm{L}-$ Lysine $\mathrm{HCL})=3.3 \%$, Methionine (DL-Methionine) $=0.95 \%$; Threonine (L-Threonine) $=3.3 \%$; Calcium $\left(\mathrm{CaCO}_{3}\right)$ $=20 \%$, Digestible Phosphorus $(\mathrm{DCP})=5.6 \%$; Salt $(\mathrm{NaCL})=12.5 \%$ and Carrier (Rice hull).

and 2 to match the changing requirements as pigs mature. Feed was given to pig ad libitum and was provided 4 times per day (at 07:00, 11:00, 16:00 and 18:00) so they were able to eat all that they wanted. Water was given to pig freshly and available for pig every time they needed.

\subsection{Data Collection}

Feed offered and residual feed were weighted and recorded daily to determine average of daily feed intake (ADFI). Sub-samples of both grades of rice bran and soybean meal were collected from every batch purchased to know the variation between purchases over time. Samples of treatment diets were collected every week and composite samples were sent to Chemical Analysis Laboratory, Royal University of Agriculture, Phnom Penh to analyzes the chemical composition. Residual feed samples were also sent to laboratory to analyze for dry matter to calculate feed intake on dry matter basis. Pigs were weighted individually on 0 , 21 and 52 day of the experiment to calculate body weight (BW), average daily gain (ADG) and feed efficiency (F/G).

\subsection{Chemical Analysis}

Feed ingredients and experimental diets (offer and residues) were analyzed for their chemical composition (dry matter, crude protein, organic matter, crude fiber, and fat). Dry matter and organic matter were analyzed for proximate principle according to AOAC [14]. Crude protein was analyzed by LECO machine (FP-528, LECO Corporation, ISO-9001:2008, USA, 2014), Crude fiber was de- 
termined by ANKOM 200i (ANKOM Technology, USA) approved procedure by AOCS and fat was determined by ST 243 Soxtec $^{\mathrm{TM}}$ Extraction Unit (Foss Analytical Co., Ltd., China, 2014).

\subsection{Data Analysis}

Body weight, average of daily weight gain, feed intake and feed efficiency were analyzed as a randomized incomplete block design in a $2 \times 2$ factorial using SAS program. Sources of variation were two grades of rice bran (high-quality rice bran and low-quality rice bran), type of supplement (protein supplement and soybean meal with base mix) and error. The analytical procedure was processed with one-way of analysis of variance (ANOVA-test) to compare the variable means and determined the statistically significant difference of means at the probability level $(\mathrm{P}<0.05)$.

\section{Results}

Chemical composition and variation of feed ingredients are shown in Table 2. High-quality rice bran had higher crude protein and fat, and lower crude fiber then the low quality rice bran, as expected, and was similar to grade 2 rice bran reported by Sreng [11]. For the low quality rice bran, its nutrient profile was generally consistent with a grade 3 rice bran, the poorest quality classification [11]. The protein supplement and soybean meal had similar values for crude protein and crude fiber content.

Diet analysis was similar to expectations based on the analysis of individual ingredients used in each diet. Diets containing high-quality rice bran had greater crude protein and fat and lower crude fiber than diets containing low-quality rice bran. As experimentally designed, crude protein of diets with soybean meal and base mix was approximately $2 \%$ greater during phase 1 than during phase 2 . Decreasing the ratio of soybean meal in the diet decreased the percentage of total crude protein in diet. Due to supplement inclusion rates being similar in phase 1 and 2, diet analysis for diets containing supplement was similar in both phases (Table 3).

The effect of rice bran, protein supplement, base mix and soybean meal on the growth rate of pigs is shown in Table 4. Interactions between rice bran quality

Table 2. Chemical composition and variation of feed ingredients (\%DM).

\begin{tabular}{ccccc}
\hline Items & $\begin{array}{c}\text { High-quality } \\
\text { rice bran }\end{array}$ & $\begin{array}{c}\text { Low-quality } \\
\text { rice bran }\end{array}$ & Soybean meal & $\begin{array}{c}\text { Protein } \\
\text { supplement }\end{array}$ \\
\cline { 2 - 5 } & $\mathrm{n}=5$ & $\mathrm{n}=6$ & $\mathrm{n}=3$ & $\mathrm{n}=1$ \\
\hline Dry matter & $92.91 \pm 1.01$ & $92.54 \pm 0.92$ & $90.82 \pm 0.35$ & 93.10 \\
Crude protein & $11.07 \pm 1.15$ & $5.86 \pm 0.41$ & $46.10 \pm 0.64$ & 46.43 \\
Organic Matter & $89.66 \pm 2.07$ & $85.08 \pm 0.64$ & $92.15 \pm 0.08$ & 81.94 \\
Crude Fiber & $13.44 \pm 2.08$ & $27.79 \pm 1.59$ & $3.57 \pm 0.14$ & 3.67 \\
Fat & $11.20 \pm 0.93$ & $4.50 \pm 0.91$ & $1.09 \pm 0.35$ & 4.44
\end{tabular}


Table 3. Chemical composition of diets ${ }^{\mathrm{a}}$.

\begin{tabular}{cccccc}
\hline Parameter & DM (\%) & CP (\%) & OM (\%) & CF (\%) & Fat (\%) \\
\hline Phase 1 & $(\mathbf{1 6}-\mathbf{2 7}$ kg of body weight) & & \\
HRB + SBM + BM & 90.93 & 18.87 & 91.05 & 9.46 & 8.80 \\
HRB + PS & 91.64 & 16.30 & 90.33 & 10.31 & 8.30 \\
LRB + SBM + BM & 91.69 & 15.26 & 85.87 & 22.32 & 3.37 \\
LRB + PS & 91.96 & 12.73 & 85.05 & 25.3 & 3.48 \\
& Phase 2 $(27-\mathbf{4 8 ~ k g}$ of body weight $)$ & & \\
HRB + SBM + BM & 91.63 & 16.73 & 88.68 & 11.34 & 7.12 \\
HRB + PS & 92.79 & 16.81 & 88.91 & 11.71 & 8.42 \\
LRB + SBM + BM & 92.17 & 12.81 & 84.95 & 23.59 & 4.12 \\
LRB + PS & 91.37 & 12.95 & 84.81 & 23.48 & 5.14 \\
\hline
\end{tabular}

${ }^{\mathrm{a}} \mathrm{HRB}=$ High-quality rice bran, $\mathrm{LRB}=$ Low-quality rice bran, $\mathrm{SBM}=$ Soybean meal, $\mathrm{BM}=\mathrm{Base}$ mix, $\mathrm{PS}=$ Protein supplement.

Table 4. Effect of rice bran quality and protein supplement, base mix, and/or soybean meal on growing pig performance ${ }^{\mathrm{d}, \mathrm{e}}$.

\begin{tabular}{|c|c|c|c|c|c|c|c|c|}
\hline \multirow[b]{2}{*}{ Item } & \multicolumn{2}{|c|}{ HRB } & \multicolumn{2}{|c|}{ LRB } & \multirow[b]{2}{*}{ SEM } & \multicolumn{3}{|c|}{$P$-value } \\
\hline & $\mathrm{SBM}+\mathrm{BM}$ & PS & $\mathrm{SBM}+\mathrm{BM}$ & PS & & $\begin{array}{c}\text { Rice Bran } \\
\text { Source }\end{array}$ & $\begin{array}{l}\text { Protein } \\
\text { Source }\end{array}$ & $\begin{array}{c}\text { Rice Bran } \\
\times \text { Source }\end{array}$ \\
\hline \multicolumn{9}{|c|}{ Body weight, kg } \\
\hline D 0 & 16.14 & 16.20 & 16.12 & 16.12 & 0.04 & 0.262 & 0.416 & 0.416 \\
\hline D 21 & $26.79^{\mathrm{a}}$ & $26.14^{\mathrm{a}}$ & $24.40^{\mathrm{b}}$ & $23.36^{\mathrm{b}}$ & 0.06 & $<0.001$ & 0.133 & 0.718 \\
\hline D 52 & $48.19^{\mathrm{a}}$ & $48.12^{\mathrm{a}}$ & $43.64^{\mathrm{b}}$ & $42.91 \mathrm{~b}$ & 0.10 & $<0.001$ & 0.668 & 0.717 \\
\hline \multicolumn{9}{|c|}{ Phase 1 (Day 0 - 21) } \\
\hline ADG, $g$ & $507^{\mathrm{a}}$ & $473^{\mathrm{a}}$ & $394^{\mathrm{b}}$ & $345^{\mathrm{b}}$ & 26.8 & $<0.001$ & 0.112 & 0.756 \\
\hline ADFI, $g$ & $1299^{\mathrm{ab}}$ & $1209^{\mathrm{b}}$ & $1325^{\mathrm{a}}$ & $1267^{\mathrm{ab}}$ & 34.9 & 0.211 & 0.038 & 0.616 \\
\hline $\mathrm{F} / \mathrm{G}$ & $2.58^{\mathrm{b}}$ & $2.63^{\mathrm{b}}$ & $3.36^{\mathrm{a}}$ & $3.68^{\mathrm{a}}$ & 0.17 & $<0.001$ & 0.267 & 0.411 \\
\hline \multicolumn{9}{|c|}{ Phase 2 (Day $21-52$ ) } \\
\hline ADG, $g$ & $690^{\mathrm{a}}$ & $709^{\mathrm{a}}$ & $621^{\mathrm{b}}$ & $631^{\mathrm{b}}$ & 19.1 & 0.001 & 0.418 & 0.795 \\
\hline ADFI, $g$ & $2139^{\mathrm{a}}$ & $1965^{\mathrm{b}}$ & $2422^{\mathrm{a}}$ & $2465^{\mathrm{a}}$ & 75.1 & $<0.001$ & 0.356 & 0.136 \\
\hline $\mathrm{F} / \mathrm{G}$ & $3.10^{\mathrm{b}}$ & $2.78^{\mathrm{c}}$ & $3.90^{\mathrm{a}}$ & $3.91^{\mathrm{a}}$ & 0.10 & $<0.001$ & 0.123 & 0.097 \\
\hline \multicolumn{9}{|c|}{ Overall (Day 0 - 52) } \\
\hline ADG, $g$ & $616^{\mathrm{a}}$ & $614^{\mathrm{a}}$ & $529^{\mathrm{b}}$ & $515^{\mathrm{b}}$ & 19.0 & $<0.001$ & 0.640 & 0.740 \\
\hline ADFI, $g$ & $1800^{\mathrm{b}}$ & $1660^{\mathrm{b}}$ & $1979^{\mathrm{a}}$ & $1981^{\mathrm{a}}$ & 54.4 & $<0.001$ & 0.188 & 0.173 \\
\hline $\mathrm{F} / \mathrm{G}$ & $2.93^{\mathrm{b}}$ & $2.72^{\mathrm{b}}$ & $3.74^{\mathrm{a}}$ & $3.85^{\mathrm{a}}$ & 0.12 & $<0.001$ & 0.678 & 0.185 \\
\hline
\end{tabular}

${ }^{\mathrm{a}, \mathrm{b}, \mathrm{c}, \mathrm{C}}$ Means within main effects within rows without common letter are different, $\mathrm{P}<0.05$; ${ }^{\mathrm{d}}$ HRB: High-quality rice bran, LRB: Low-quality rice bran, SMB: Soybean meal, BM: Base mix, PS: Protein supplement; ${ }^{\mathrm{e}} \mathrm{ADG}$ : Average daily gain, ADFI: Average daily feed intake, F/G: Feed efficiency.

and supplement type or effects of supplement type (soybean meal + base mix or protein supplement) on body weight, ADG, ADFI and F/G at day 21, 52 and 
overall were not significant in this study. However, rice bran quality significantly affected body weight, ADG, ADFI and F/G with pigs fed diets containing high-quality rice bran having improved $(\mathrm{P}<0.001)$ ADG and F/G compared with pigs fed diets with lower quality rice bran during both phases and overall. Pigs fed diets containing high-quality rice bran also had lower ADFI $(\mathrm{P}<0.001)$ from $\mathrm{d} 21$ to 52 and overall than pigs fed low-quality rice bran.

For effect of added protein source to the diet, pigs fed diets with protein supplement had lower $(\mathrm{P}=0.038)$ ADFI from $\mathrm{d} 0$ to 21 than pigs fed diets containing soybean meal and base mix. However, no overall differences in growth or body weight were found between pigs fed either the protein supplement or soybean meal and base mix.

\section{Discussion}

High-quality rice bran in this study had a higher percentage of crude protein and fat and corresponding low crude fiber. In contrast, low-quality rice bran had lower percentage of crude protein and fat but a high percentage of crude fiber. Likewise, Samkol [1] reported that rice bran is classified into 3 grades (1, 2 and 3) based on crude protein, crude fiber content and market price. The third grade has significant amounts of husks which has a high content of fiber and poorer quality. However, a variety of factors associated with the rice grain itself and the milling process affect the chemical composition of rice bran [15] [16] [17]. The crude protein levels for rice bran in this study were $5.86 \%$ and $11.07 \%$, which are within the range (3.37\% to $16.20 \%)$ of other previous data [1] [7] [9] [13] [17] [18] [19] [20] [21]. The crude fiber levels of rice brans in the present study were $13.44 \%$ and $27.79 \%$ which agree with the others that reported crude fiber content of rice bran in ranges from $6.13 \%$ to $28.6 \%$ [9] [13] [15] [17] [18] [19]. Rice brans used in this study contained $4.5 \%$ and $11.2 \%$ fat which are similar to the range of $4.7 \%$ to $22.6 \%$ reported by Saunder [17]. The high- and low-quality rice bran would be considered grade 2 and 3 respectively, based on Samkol [1].

Soybean meal used in this experiment contained $46.10 \%$ crude protein (CP) which was lower than the result of Sreng [13] who reported that soybean meal contained $50.45 \% \mathrm{CP}$ on dry matter (DM) basis. However, it was within the range $(42.7 \%$ to $51.1 \%)$ of other reports [22]. The value of crude fiber and fat were $3.57 \%$ and $1.09 \%$, which was similar to previous report [13] and were within the range of $2.8 \%$ to $7.7 \%$ for crude fiber and $0.5 \%$ to $2.6 \%$ for fat, respectively [22]. Wang [23] describe that soybean meal in different areas has different protein and AA concentrations. However, the differences in processing mill conditions such as temperature, moisture, residence time and fineness may result in soybean meal of varying quality and nutrient composition [22]. Soybean meal processors must ensure soybean meal is adequately processed to a high enough temperature to reduce anti-nutritional factors that result in decreased growth performance [24]. Analysis of protein supplement was confirmed that it has a high protein $(46 \% \mathrm{CP})$. Chemical composition of diets including soybean 
meal and base mix were changed as expected with the percentage of ingredient changes.

Type of supplements (soybean meal + base mix or protein supplement) did not influence body weight, ADG, and F/G from day 0 to 21, 21 to 52 and overall (d 0 to 52) of the study. These results indicate that both methods of supplementation provided adequate nutrients to achieve similar growth performance. Results also agree with Sreng [13] who found that feeding pig a rice bran diet with soybean meal and base mix compared to feeding a rice bran diet with high protein supplement had similar growth performance.

The quality of rice bran significantly affected final body weight (+11\%), ADG $(+18 \%)$, ADFI $(-13 \%)$ and $\mathrm{F} / \mathrm{G}(-26 \%)$ when comparing high vs. low-quality rice bran. The two rice bran sources had different percentage of crude protein, crude fiber and fat which was likely the main reason for differences in pig growth performance. High-quality rice bran diets improved ADG and F/G and decreased ADFI, which may have been caused by the high fat and low crude fiber content. The significantly higher crude fiber of the low-quality rice bran most likely contributed to the slower growth rate and poorer feed efficiency due to a lower energy content. This agreed with earlier reports by Chanphone [10] and Sikka and Chawla [25] who demonstrated that the quality of rice bran with respect to crude fiber affects the growth rates and digestibility in growing pigs. Also, ingredients with higher dietary fiber had decreased DE concentration of the diet [26]. Additionally, Samkol [1] reported that third grade of rice bran has a lot amount of husk and it has a high content of fiber, which pigs either do not or minimally digest.

Shi [16] showed that DE and ME content among 17 samples of rice brans ranged widely and correlated with fat. The differences in fat content between rice brans reflect difference in their energy content [27]. Low energy diets containing higher level of fiber will depress the growth rate under high environmental temperature. Cho [28] showed that increasing the energy density of the diet improved ADG and F/G on growing pig. Conversely, increased dietary fiber level is associated with a reduced available energy content of the feed [29]. Using prediction equations developed by Shi [16], the high-quality rice bran in our study contained $20 \%$ greater metabolizable energy than the low-quality rice bran ( $2886 \mathrm{kcal} / \mathrm{kg}$ vs $2290 \mathrm{kcal} / \mathrm{kg}$, respectively).

Finally, the diets of high-quality rice bran also had a greater percentage of $\mathrm{CP}$ than diets with low-quality rice bran. Thus, the level of protein in the diet also may have affected the growth performance of pigs. Cunha [30] reported that if protein level in diet is low, it will decrease feed intake, rate of weight gain and feed efficiency. Moreover, significant reductions in body weight gain by using rice bran up to $82 \%$ in diet were associated with lower CP and NFE and reduced digestibility of nutrient [18]. There is considerable variation in the nutritive value of different samples of rice bran, as shown by large variation in amino acid digestibility values [27]. 


\section{Conclusion}

In conclusion, rice bran quality as measured by protein, crude fiber, and fat influenced growing pig performance but the type of dietary protein supplement did not. Rice bran with high protein, high fat, and low fiber improved ADG and F/G.

\section{Acknowledgements}

This research is made possible by the generous support of the American people through the United States Agency for International Development. The contents are the responsibility of the Horticulture Innovation Lab and do not necessarily reflect the views of USAID or the United States Government. Sincere thank you to the Graduate School Laboratory, Royal University of Agriculture for kindly supporting this research. Also thank you to Mr. Mao MAN and Mr. Sambol MOUEN for assisting with pig care and data collection on the farm, and Miss Choronai Mouch who helped conduct chemical analysis.

\section{Conflicts of Interest}

The authors declare no conflicts of interest regarding the publication of this paper.

\section{References}

[1] Samkol, P., Borin, K. and Sovann, S. (2006) Pig Systems in Southeast Asia-The Case of Cambodia. Proceedings of Pig Systems in Asia and the Pacific. How Can Research and Development Enhance Benefits to the Poor, Bangkok, 23-24 November 2006, 34-42. http://cdn.dairyasia.org/APHCA/dmdocuments/PAP_06_Asia_Pig_Systems_Ws.pdf

[2] Ministry of Agriculture, Forestry and Fisheries (2020) Annual Report for Animal Health and Production 2018-2019 and Direction 2019-2020. Cambodia, 7-12.

[3] Borin, K., Soeun, T., Preston, T.R. and Sato, K. (1996) The Role of the Sugar Palm Tree (Borassus flabellifer) in Livestock Based Farming Systems in Cambodia. National Seminar on Sustainable Livestock Production on Local Feed Resources, Ho Chi Minh City, 10-14.

[4] General Directorate of Animal Health and Production (2019) A Guidebook on Pig Raising and Management Techniques. Cambodia, 1-5.

[5] Sokha, T., Preston, T.R. and Borin, K. (2008) Effect of Different Protein Levels Derived from Mixtures of Water Spinach and Fresh Sweet Potato Vines in Basal Diets of Broken Rice or Cassava Root Meal and Rice Bran for Growing Pigs. Livestock Research for Rural Development, 20, Supplement. http://www.lrrd.org/lrrd20/supplement/sokh.htm

[6] Rozemuller, M.A. (1998) From Pig Rearing to Stock Marketing: Rice Milling, a Broad Spectrum of Entrepreneurial Activities. Occasional Paper/Center for Advance Study, Series No. 1, Phnom Penh, 51.

[7] Phiny, C., Ogle, B., Preston, T.R. and Borin, K. (2008) Digestibility and N-Retention in Crossbred Pigs of Diets with Water Spinach or Water Spinach Mixed with Mulberry Leaves as Protein Sources in Basal Diets of Cassava Root Meal plus Rice Bran, or Sugar Palm Syrup plus Broken Rice. Livestock Research for Rural Development, 
20, Supplement. http://www.lrrd.org/lrrd20/supplement/phin1.htm

[8] Chhay, T., Borin, K. and Preston, T.R. (2007) Effect of Mixtures of Water Spinach and Fresh Water Hyacinth Leaves on Growth Performance of Pigs Fed a Basal Diet of Rice Bran and Cassava Root Meal. Livestock Research for Rural Development, 19, Article \#194. http://www.lrrd.org/lrrd19/12/chha19194.htm

[9] Malavanh, C. and Preston, T.R. (2006) Intake and Digestibility by Pigs Fed Different Levels of Sweet Potato Leaves and Water Spinach as Supplements to a Mixture of Rice Bran and Cassava Root Meal. Livestock Research for Rural Development, 18, Article \#86. http://www.lrrd.org/lrrd18/6/mala18086.htm

[10] Chanphone, K. and Choke, M. (2003) Growth Performance of Indigenous Pigs Fed with Stylosanthes guianensis CIAT 184 as Replacement for Rice Bran. Livestock Research for Rural Development, 15, Supplement.

http://www.lrrd.org/lrrd15/9/chan159.htm

[11] Sreng, S., Chea, B., Kang, K., Keo, S., Tokach, M.D., Tokach, L.M., Hok, L., Vipham, J.L. and DeRouchey, J.M. (2020) Nutrient Analysis of Common Local Feed Ingredients Used by Swine Farmers in Cambodia. Livestock Research for Rural Development, 32, Article \#103. http://www.lrrd.org/lrrd32/7/mtoka32103.html

[12] Prak, K., Preston, T.R. and Ly, J. (2003) Feed Intake, Digestibility and N Retention of a Diet of Water Spinach Supplemented with Palm Oil and/or Broken Rice and Dried Fish for Growing Pigs. Livestock Research for Rural Development, 15, Article \#60. http://www.lrrd.org/lrrd15/8/kea158.htm

[13] Sreng, S., Keo, S., DeRouchey, J.M., Tokach, M.D., Chea, B., Kang, K., Hok, L. and Vipham, J.L. (2020b) Effect of Dietary Supplement, Base Mix, and/or Soybean Meal on Growing Pig Performance. Open Journal of Animal Sciences, 10, 535-544. https://doi.org/10.4236/ojas.2020.103034

[14] AOAC (1995) Official Method of Analysis. 16th Edition, Animal Feeds, Association of Official Analytical Chemists, Arlington.

[15] Bor, S.L., Barber, S. and Benedito de Barber, C. (1991) Rice Bran: Chemistry and Technology. In: Bor, S.L., Ed., Rice-Utilization, 2nd Edition, Volume II, Van Nostrand Reinhold, New York, 313-362.

[16] Shi, C.X., Liu, Z.Y., Shi, M., Li, P., Zeng, Z.K., Liu, L., Huang, C.F., Zhu, Z.P. and Li, D.F. (2015) Prediction of Digestible and Metabolizable Energy Content of Rice Bran Fed to Growing Pigs. Asian-Australasian Journal of Animal Sciences, 28, 654-661. https://doi.org/10.5713/ajas.14.0507

[17] Saunders, R.M. (1986) Rice Bran: Composition and Potential Food Uses. Food Reviews International, 1, 465-495. https://doi.org/10.1080/87559128509540780

[18] Soren, N.M., Bhar, R., Chabbra, A.K. and Mandal, A.B. (2003) Performance of Crossbred Gilts Fed on Diets with Higher Levels of Fat and Fibre through Addition of Rice Bran. Asian-Australasian Journal of Animal Sciences, 16, 1650-1655. https://doi.org/10.5713/ajas.2003.1650

[19] Li, Y., Li, Z., Liu, H., Noblet, J., Liu, L., Li, D., Wang, F. and Lai, C. (2018) Net Energy Content of Rice Bran, Corn Germ Meal, Corn Gluten Feed, Peanut Meal, and Sunflower Meal in Growing Pigs. Asian-Australasian Journal of Animal Sciences, 31, 1481-1490. https://doi.org/10.5713/ajas.17.0829

[20] Casas, G.A. and Stein, H.H. (2016) Effects of Full Fat or Defatted Rice Bran on Growth Performance and Blood Characteristics of Weanling Pigs. Journal of Animal Sciences, 94, 4179-4187. https://doi.org/10.2527/jas.2016-0565

[21] Ngoc, T.T.B., Len, N.T. and Lindberg, J.E. (2012) Effect of Fibre Level and Fibre Source on Gut Morphology and Micro-Environment in Local (Mong Cai) and Ex- 
otic (Landrace $\times$ Yorkshire) Pigs. Asian-Australasian Journal of Animal Sciences, 25, 1726-1733. https://doi.org/10.5713/ajas.2012.12305

[22] Thakur, M. and Hurburgh, C.R. (2007) Quality of US Soybean Meal Compared to the Quality of Soybean Meal from Other Origins. Journal of the American Oil Chemists' Society, 84, 835-843. https://doi.org/10.1007/s11746-007-1107-8

[23] Wang, J.P., Hong, S.M., Yan, L., Cho, J.H., Lee, H.S. and Kim, I.H. (2011) The Evaluation of Soybean Meals from 3 Major Soybean-Producing Countries on Productive Performance and Feeding Value of Pig Diets. Journal of Animal Science, 89, 2768-2773. https://doi.org/10.2527/jas.2009-1800

[24] Lawrence, K.R., Hastad, C.W., Hanni, S.M., Young, M.G., Webster, M.J., Barker, M.R., James, B.W., Groesbeck, C.N., Goodband, R.D., Tokach, M.D., Nelssen, J.L., DeRouchey, J.M. and Dritz, S.S. (2002) Effects of Soybean Meal Source and Level on Growth Performance of Weanling Pigs. Kansas Agricultural Experiment Station Research Report. https://doi.org/10.4148/2378-5977.6760

[25] Sikka, S.S. and Chawla, J.S. (1984) Effect of Quality of Rice Bran on the Performance of Growing Pigs. Journal of Research of Punjab Agricultural University, 21, 457-459.

[26] NRC (1998) Nutrient Requirements of Swine. 10th Edition, National Academy Press, Washington DC.

[27] Kaufmann, C., Sauer, W.C., Cervantes, M., Zhang, Y., He, J., Rademacher, M. and Htoo, J.K. (2005) Amino Acid and Energy Digestibility in Different Sources of Rice Bran for Growing Pigs. Canadian Journal of Animal Science, 85, 355-363. https://doi.org/10.4141/A04-084

[28] Cho, S.B., Han, I.K., Kim, Y.Y., Park, S.K., Hwang, O.H., Choi, C.W., Yang, S.H., Park, K.H., Choi, D.Y. and Yoo, Y.H. (2012) Effect of Lysine to Digestible Energy Ratio on Growth Performance and Carcass Characteristics in Finishing Pigs. Asian-Australasian Journal of Animal Sciences, 25, 1582-1587. https://doi.org/10.5713/ajas.2012.12311

[29] Noblet, J. and Le Goff, G. (2001) Effect of Dietary Fibre on the Energy Value of Feeds for Pigs. Animal Feed Science and Technology, 90, 35-52. https://doi.org/10.1016/S0377-8401(01)00195-X

[30] Cunha, T.J. (1997) Swine Feeding and Nutrition. In: Cunha, T.J., Ed., Animal Feeding and Nutrition: A Series of Monographs, Academic Press Inc., New York, 139-158. 